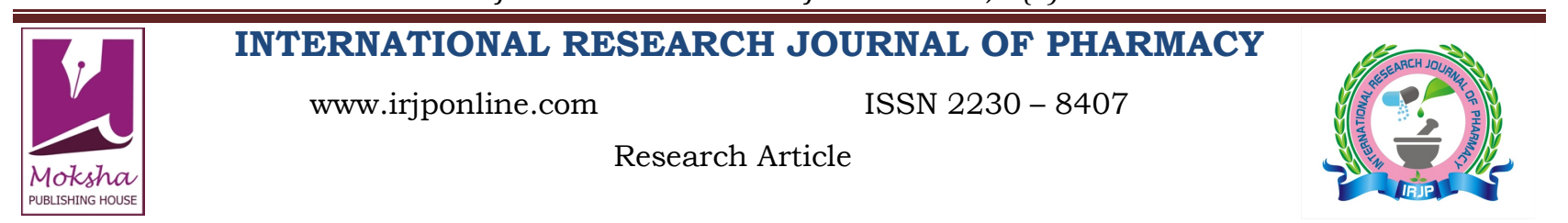

\title{
EFFECT OF QUERCETIN ON HEPATOPROTECTIVE ACTIVITY OF SILYMARIN AGAINST THIOACETAMIDE INTOXICATED RATS
}

Jashitha M, Manodeep Chakraborty*, Jagadish V Kamath

Department of Pharmacology, Shree Devi College of Pharmacy, Mangalore, Karnataka state, India

*Corresponding Author Email: manodeep.chakraborty@gmail.com

Article Received on: 17/03/13 Revised on: 01/04/13 Approved for publication: 10/05/13

DOI: $10.7897 / 2230-8407.04730$

IRJP is an official publication of Moksha Publishing House. Website: www.mokshaph.com

(C) All rights reserved.

\section{ABSTRACT}

The study was designed to investigate the interactive effect of Quercetin on hepatoprotective effect of Silymarin against thioacetamide induced hepatotoxicity in rats. Albino rats of either sex were divided into six groups and treated for 7 days. Group 1 and 2 served as normal and toxic control and other groups were treated with Silymarin $(100 \mathrm{mg} / \mathrm{kg})$, Quercetin $(100 \mathrm{mg} / \mathrm{kg})$, high and low dose combination of Silymarin $(100 \mathrm{and} 50 \mathrm{mg} / \mathrm{kg})+$ Quercetin $(100 \mathrm{and} 50 \mathrm{mg} / \mathrm{kg})$ respectively. Liver damage was induced in by administering thioacetamide $\left(100 \mathrm{mg} / \mathrm{kg}\right.$, s.c) on $7^{\text {th }}$ day. $48 \mathrm{~h}$ after the administration of thioacetamide blood samples were collected by retro-orbital puncture method and levels of alanine aminotransferase, aspartate aminotransferase, alkaline phosphatase and bilirubin in serum were evaluated. Histopathology of liver was also carried out. The combination of Silymarin $(100 \mathrm{mg} / \mathrm{kg})+$ Quercetin $(100 \mathrm{mg} / \mathrm{kg}) \mathrm{demonstrated}$ significant reduction in enzyme and bilirubin level in serum compared to Silymarin $(100 \mathrm{mg} / \mathrm{kg})$ alone treated group which was supported by histopathological study. It can be concluded that Quercetin has got a synergistic effect on hepatoprotective action of Silymarin against thioacetamide induced hepatotoxicity. Keywords: Hepatoprotective, Silymarin, Quercetin, Thioacetamide, Histopathology.

\section{INTRODUCTION}

The liver is one of the major organs in the body responsible for maintaining the homeostasis of body. However liver is one of the most frequently injured organs in the body. Most of the synthetic drugs used in liver disease are less effective or has got serious side effects. Plant based drugs with their significant potency and lesser side effects are alternative therapeutic option ${ }^{1}$. Silymarin, which is the oldest and safest hepatoprotective drug, is a mixture of flavonolignans obtained from the seeds of Silybum marianum. Even though Silymarin is a potent antioxidant it has got poor oral bioavailability ${ }^{2}$. Quercetin, a bioactive flavonoid present in various edible fruits and vegetables, is a potent antioxidant and exhibits a wide range of biological functions ${ }^{3}$. Quercetin being a P-gp inhibitor reverse P-gp-mediated efflux and thus improves the efficiency of drug transport across the epithelia and also being able to inhibit some of the enzymes involved in drug metabolism increases the bioavailability, blood levels and efficacy of number of drugs ${ }^{4}$. The pathological lesions produced by hepatotoxins (like alcohol, thioacetamide, $\mathrm{CCl}$, etc) may be similar to many forms of liver disease, which helps in evaluation of potential hepatoprotectants 5 . Therefore the present study was carried out to evaluate the interactive effect of Quercetin in hepatoprotective activity of Silymarin against thioacetamide (TAA) induced hepatotoxicity in rats.

\section{MATERIALS AND METHOD}

\section{Procurement of Quercetin and its dose selection}

Pure quercetin was procured from Yucca Enterprises, Mumbai, India in the month of December, 2012. Based on earlier reported study the high and low dose of Quercetin ${ }^{6}$ and Silymarin ${ }^{7,8}$ was selected as $100 \mathrm{mg} / \mathrm{kg}$ p.o. and 50 $\mathrm{mg} / \mathrm{kg}$ p.o. respectively. A suspension of Quercetin and Silymarin was prepared using Carboxy methyl cellulose (1\%) and administered orally using gastric intubation using a force feeding needle.

\section{Animals}

Albino rats of either sex weighing 150-250 g were housed at $25^{\circ} \pm 5^{\circ} \mathrm{C}$, relative humidity $50 \pm 5 \%$ in a well-ventilated animal house under $12: 12 \mathrm{~h}$ light dark cycle. Institutional Animal Ethics Committee approved the experimental protocol. The animals were maintained under standard conditions in the animal house as per the guidelines of Committee for the Purpose of Control and Supervision on Experiments on Animals (CPCSEA).

\section{Chemicals}

Sodium chloride (RFCL Limited, New Delhi, India), Carboxy Methyl Cellulose (PRS Pharma, Private Limited, Salem, India), Thioacetamide (Sigma Aldrich, U.S.A), ketamine (Neon Labs, India) all the chemicals used was of analytical grade and the enzyme kits used were ALT (Robonik India Pvt Ltd, Mumbai, India), AST (Robonik India Pvt Ltd, Mumbai, India), ALP (Robonik India Pvt Ltd, Mumbai, India), Bilirubin (total and direct) (Robonik India Pvt Ltd, Mumbai, India).

\section{Thioacetamide induced liver necrosis in rats}

Rats were divided into six groups of six animals each. The animals were then subjected to either one of the following treatments for 7 days. On $7^{\text {th }}$ day thioacetamide (TAA) was administered. $^{9}$

The groups were as follows;

Group I- Vehicle; $1 \mathrm{ml} / 250$ g, p.o. (Normal control)

Group II- TAA (100 mg /kg, s.c.) (Toxic control)

Group III- Silymarin (100 mg/kg/day, p.o.) for 7 days + TAA $(100 \mathrm{mg} / \mathrm{kg}$, s.c.) on seventh day. (Standard)

Group IV- Quercetin (100 mg/kg/day, p.o.) for 7 days + TAA (100 mg $/ \mathrm{kg}$, s.c.) on seventh day.

Group V- Silymarin (50 mg/kg/day, p.o.) + Quercetin (50 $\mathrm{mg} / \mathrm{kg} /$ day, p.o.) for 7 days + TAA (100 mg $/ \mathrm{kg}$, s.c.) on seventh day.

Group VI- Silymarin (100 mg/kg/day, p.o.) + Quercetin (100 $\mathrm{mg} / \mathrm{kg} /$ day, p.o.) for 7 days + TAA (100 mg $/ \mathrm{kg}$, s.c.) on seventh day. 


\section{Estimation of biochemical parameters}

$48 \mathrm{~h}$ after the administration of thioacetamide, blood samples were collected by retro-orbital puncture method into plain tubes and then serum was isolated by centrifuging at 5000 rpm for $10 \mathrm{~min}$. The isolated serum was then subjected for the assay of marker enzymes, namely, alanine aminotransferase (ALT), aspartate aminotransferase (AST), alkaline phosphatase (ALP) and serum bilirubin (total and direct) levels using reagent kits of Robonik (India) private limited and by using a automated analyzer.

\section{Histopathological study}

After the blood samples were collected, animals were sacrificed and the liver from each group were isolated and preserved in $10 \%$ formalin solution. After paraffin embedding, tissues were sectioned and stained with hematoxylin and eosin (HandE) for observing microscopic changes in the liver.

\section{Statistical Analysis}

Results are expressed as Mean \pm SEM. Statistical significance was assessed using One-Way Analysis of Variance (ANOVA) followed by Turkey-karmer multiple comparison test. $\mathrm{P}<0.05$ was considered significant.

Table 1: Effect of Silymarin and Quercetin on serum ALT, AST, ALP, bilirubin (total and direct) in TAA induced liver necrosis in rats

\begin{tabular}{|c|c|c|c|c|c|}
\hline Treatment & ALT (U/L) & AST (U/L) & $\operatorname{ALP}(\mathbf{U} / L)$ & $\begin{array}{c}\text { Total Bilirubin } \\
(\mathrm{mg} / \mathrm{dl})\end{array}$ & $\begin{array}{c}\text { Direct Bilirubin } \\
(\mathrm{mg} / \mathrm{dl})\end{array}$ \\
\hline Vehicle control & $61.48 \pm 3.36$ & $144.96 \pm 3.97$ & $212.60 \pm 4.33$ & $15.93 \pm 1.10$ & $0.33 \pm 0.01$ \\
\hline Toxic control (TAA) & $514.07 \pm 9.65^{* * *}$ & $859.66 \pm 9.16^{* * *}$ & $1095.83 \pm 5.98^{* * *}$ & $65.78 \pm 2.48 * * *$ & $75 \pm 0.02 * * *$ \\
\hline Silymarin $(100 \mathrm{mg} / \mathrm{kg})$ & $\begin{array}{c}120.43 \pm \\
2.71 * * * 000\end{array}$ & $251.03 \pm 10.65 * * * 000$ & $\begin{array}{c}294.30 \pm \\
6.95 * * * 000\end{array}$ & $32.73 \pm 0.81 * * * 000$ & $51 \pm 0.01 * * * 000$ \\
\hline Quercetin $(100 \mathrm{mg} / \mathrm{kg})$ & $97.66 \pm 3.52 * * 000$ & $210.46 \pm 8.19 * * * 000$ & $235.00 \pm 2.88000$ & $24.81 \pm 0.89 * * 000$ & $0.37 \pm 0.01000$ \\
\hline $\begin{array}{c}\text { Silymarin }(50 \mathrm{mg} / \mathrm{kg})+ \\
\text { Quercetin }(50 \mathrm{mg} / \mathrm{kg})\end{array}$ & $\begin{array}{c}110.00 \pm \\
2.88 * * * 000\end{array}$ & $253.00 \pm 5.82 * * * 000$ & $\begin{array}{c}300.00 \pm 5.77 * * * \\
000\end{array}$ & $32.10 \pm 0.63 * * * 000$ & $0.47 \pm 0.00^{* * *} 000$ \\
\hline $\begin{array}{c}\text { Silymarin }(100 \mathrm{mg} / \mathrm{kg})+ \\
\text { Quercetin }(100 \mathrm{mg} / \mathrm{kg})\end{array}$ & $78.33 \pm 4.05000 \# \# \#$ & $152.04 \pm 6.05000 \# \# \#$ & $\begin{array}{c}214.00 \pm \\
2.08000 \# \# \#\end{array}$ & $18.45 \pm 0.58000 \# \# \#$ & $0.28 \pm 0.00000 \# \# \#$ \\
\hline
\end{tabular}

All values are mean $\pm \mathrm{SEM}, \mathrm{n}=6, * \mathrm{P}<0.05, * * \mathrm{P}<0.01, * * * \mathrm{P}<0.001$ when compared to vehicle control, $000 \mathrm{P}<0.001$ compared to toxic control and $\# \# \mathrm{P}<0.001$ when compared to Silymarin $(100 \mathrm{mg} / \mathrm{kg})$

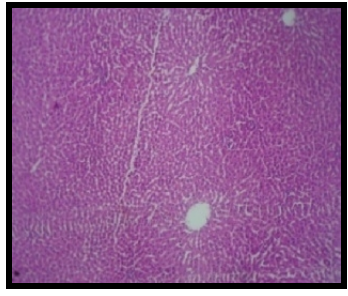

Figure 1a: Vehicle control Normal texture of liver tissue

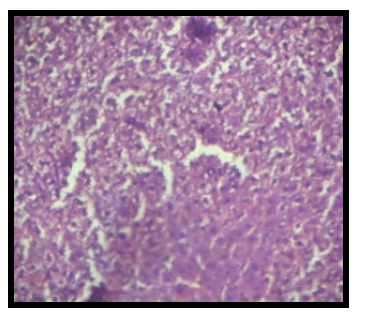

Figure 1b: Toxic control (TAA 100 mg/kg)

Severe tissue degranulation

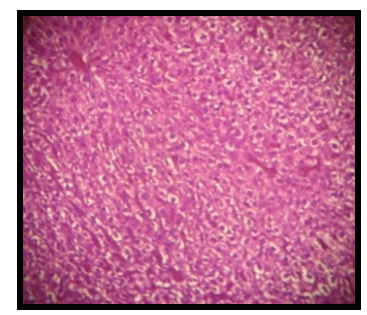

Figure 1c: Silymarin $(100 \mathrm{mg} / \mathrm{kg})$ Mild to moderate liver tissue degranulation

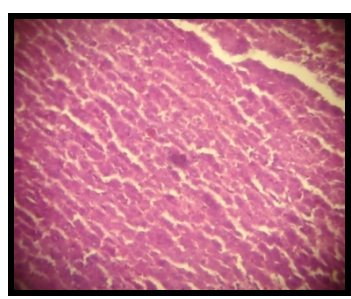

Figure 1d: Silymarin $(100 \mathrm{mg} / \mathrm{kg})+$ Quercetin (100 mg/kg) Mild tissue degranulation

Figure 1: Haematoxylin and eosin (Hand E) stained section of liver in TAA induced acute liver toxicity. Photographed at magnification 100X

\section{RESULTS}

As shown in Table 1, it was documented that the toxic control demonstrated an extremely significant increase $(\mathrm{p}<0.001)$ in serum ALT, AST, ALP and bilirubin levels when compared to normal control indicating liver damage. All other prophylactic groups showed extremely significant $(\mathrm{P}<0.001)$ decrease in biomarker level when compared to toxic control group. It was also documented that biomarkers levels reduced significantly in the group pre-treated with combination of Silymarin $(100 \mathrm{mg} / \mathrm{kg})+$ Quercetin $(100$ $\mathrm{mg} / \mathrm{kg})$ compared to Silymarin $(100 \mathrm{mg} / \mathrm{kg})$ alone treated group.

\section{DISCUSSION}

The present study was aimed to investigate the possible interaction of Quercetin in hepatoprotective effect of Silymarin in thioacetamide induced hepatotoxicity in rats. Hepatotoxins initially damage the centrilobular regions of liver where there are high levels of cytochrome P450 oxidases which mediate their conversion to toxic intermediates, followed by reactive oxygen species (ROS) production, lipid peroxidation and release of proinflammatory cytokines Thioacetamide (TAA) induces liver damage after its metabolism to thioacetamide sulphene and sulphone, via CYP4502E1-mediated biotransformation. TAA thus cause centrilobular necrosis followed by apoptosis and periportal inflammatory cell infiltration in rat liver. TAA generates reactive oxygen species (ROS) by binding covalently to liver macromolecules. During hepatic damage cellular enzymes like Alanine aminotransferase (ALT), Aspartate aminotransferase (AST), Alkaline phosphatase (ALP) and bilirubin will leak into the serum resulting in elevating their serum concentrations. Serum levels of these enzymes are very sensitive markers employed in the diagnosis of liver diseases. ${ }^{5}$ Documented results suggested that the combination of Silymarin $(100 \mathrm{mg} / \mathrm{kg})$ and Quercetin $(100 \mathrm{mg} / \mathrm{kg})$ has more potent hepatoprotective effect than other prophylactic groups which is evident by the reduction in the elevated marker enzyme level which is an indication of stabilization of plasma membrane as well as repair of hepatic tissue damages caused by thioacetamide. The exact mechanism for the enhanced activity is not known. However 
Jashitha M et al. Int. Res. J. Pharm. 2013, 4 (7)

the enhanced activity could be due to the ability of Quercetin to inhibit P-gp efflux pump and some of the enzymes involved in drug metabolism. ${ }^{4}$ this enhanced hepatoprotective effect was also supported by histopathological report.

\section{ACKNOWLEDGEMENT}

Thanks are due to Dr. Jayaprakash, Raj Pathology lab, Balmatta, Mangalore, India for histopathological studies.

\section{REFERENCES}

1. Sharma J, Gairola S, Gaur RD, Painuli RM. The treatment of jaundice with medicinal plants in indigenous communities of the Sub-Himalayan region of Uttarakhand, India. J Ethnopharmacol 2012; 143(1): 262-91. http://dx.doi.org/10.1016/j.jep.2012.06.034 PMid:22759701

2. Flora K, Hahn M, Rosen H, Benner K. Milk thistle (Silybum marianum) for the therapy of liver disease, Am J Gastroenterol 1998; 93: 139-143. http://dx.doi.org/10.1111/j.1572-0241.1998.00139.x PMid:9468229

3. Askari G, Ghiasvand R, Feizi A, Ghanadian SM, Karimian J. The effect of quercetin supplementation on selected markers of inflammation and oxidative stress, J Res Med Sci 2012; 17(7): 637-41. PMid:23798923 PMCid:PMC3685779

4. Choi JS, Piao YJ, Kang KW. Effects of quercetin on the bioavailability of doxorubicin in rats: role of CYP3A4 and P-gp inhibition by quercetin, Arch Pharm Res 2011; 34(4): 607-13. http://dx.doi.org/10.1007/s12272011-0411-x PMid:21544726

5. Cinitia De David, Graziella Rodrigues, Silvia Bona, Luise Meurer, Javier Gonzalez Gallego, Maria Jesus Tunon, et al. Role of quercetin in preventing thioacetamide induced liver injury in rats, Toxicol Pathol 2011; 39: 949-957. http://dx.doi.org/10.1177/0192623311418680 PMid:21885874

6. Mazumdar M, Giri S, Giri A. Role of quercetin on mitomycin C induced genotoxicity: analysis of micronucleus and chromosome aberrations in vivo. Mutat Res 2011; 721(2): 147-52. http://dx.doi.org/10.1016 /j.mrgentox.2011.01.007 PMid:21256974

7. El Awady el SE, Moustafa YM, Abo-Elmatty DM, Radwan A Cisplatin-induced cardiotoxicity: Mechanisms and cardio protective strategies, Eur J Pharmacol 2011; 650(1): 335-41. http://dx.doi.org/ 10.1016/j.ejphar.2010.09.085 PMid:21034734

8. Anbarasu C, Rajkapoor B, Bhat K, Giridharan J, Amuthan AA, Satish K. Protective effect of Pisonia aculeata on thioacetamide induced hepatotoxicity in rats, Asian Pac J Trop Biomed 2012; 2(7): 511-5. http://dx.doi.org/10.1016/S2221-1691(12)60087-2

9. Ahmed A, Pillai KK, Ahmed SJ, Balani DK, Najmi AK, Marwah R, Hameed. Evaluation of hepatoprotective potential of jingrine of Thioacetamide induced liver damage in rats, Indian J Pharmacol 1999; 31: 416-521.

Cite this article as:

Jashitha M, Manodeep Chakraborty, Jagadish V Kamath. Effect of Quercetin on hepatoprotective activity of silymarin against thioacetamide intoxicated rats. Int. Res. J. Pharm. 2013; 4(7): 138-140 http://dx.doi.org/10.7897/22308407.04730 